\title{
POTENTIAL INTRODUCTION OF CELL TECHNOLOGIES TO IMPROVE DENTAL IMPLANT SURFACE PREPARING
}

\section{Sergey Kupryakhin ${ }^{1}$, Alexander Lepilin ${ }^{1 *}$, Vyacheslav Kupryakhin'2, Mikhail Postnikov³, Dmitry Domenyuk ${ }^{4}$}

\author{
${ }^{1}$ Department of Surgical Dentistry and Maxillofacial Surgery, Saratov \\ state medical university Saratov, Russia \\ ${ }^{2}$ Department of Medical Law and Bioethics, Samara State Medical \\ University, Samara, Russia \\ ${ }^{3}$ Department of Dentistry, Samara State Medical University, Samara, \\ Russia \\ ${ }^{4}$ Department of General Dentistry and Child Dentistry, Stavropol State \\ Medical University, Stavropol, Russia
}

*Corresponding Author: lepilins@mail.ru

A B STRACT - An in vitro comparative analysis was carried out focusing on biological compatibility of an uncoated titanium dental implant surface, and hydroxyapatite spray-coated titanium implant, using osteoblasts cultures and dermal human fibroblasts. Cell identification implied morphological and biochemical methods as well as flow cytometry. The biological compatibility of the samples was studied through a direct contact under conditions identical to cell cultivation. The obtained outcomes suggest that hydroxyapatite applied through plasma spraying has a certain cytotoxic effect; therefore using bioceramics-coated implants in surgical dentistry will not contribute to osseointegration at the molecular and cellular levels.

KEYW ORDS - dental implant; hydroxyapatite; cell and tissue technologies; medical titanium; cell cultivation; biocompatibility; tissue bioengineering

\section{INTRODUCTION}

Successful integration of implants and grafts into a tissue environment is the major requirement for restorative medicine. Employing cell and tissue technologies appears reasonable at the stages of biological association and functioning not only for the host tissues, yet also for the integrated foreign materials. Achieving long-term equilibrium in adaptive responses between the tissue and the implanted material (of synthetic, natural and biological origin) is the most important task that tissue engineering is facing. This issue is relevant in medicine, especially in areas like Dentistry and Maxillofacial Surgery, due to a great need for artificial bone-replacing materials, a need to restore not the anatomical features only, yet also the chewing function, using dental implants. These technologies are
Article history:

Submitted 14 April 2019

Accepted 29 July 2019 expected to increase significantly the effectiveness of traditional treatments [1-13].

The aim of osteoplasty, along with dental implant installation, is the integration of artificial materials with the tissue and long-term functioning of the entire set. The basic material used to manufacture dental implants is medical titanium, since oxide compounds on its surface contribute to the fixation and functioning of morphogenetic proteins and blood proteins involved in creating and restructuring the bone tissue [14-18].

The available published results of studies focusing on potential use of cell technologies to improve the direct and delayed dental implantation are sporadic and of fragmented nature. Experts note that optimizing osseointegration through dental implantation is extremely important for cases concerning facial aesthetics restoration and dental function where the front set of teeth is lacking, in people belonging to older age groups; in case of diabetes mellitus as well as in case of other somatic diseases that affect bone regeneration and require cell technologies [19-31].

Given the current stage of development in this new area and the state of the respective legislation, working on this issue in dentistry and microbiology can be carried out only under laboratory conditions and in experiment.

Respective literature offers numerous items by implant developers, who propose various ways to increase the materials' surface porosity aimed to improve osseointegration. Of these methods, not all ensure a positive effect on reparation, thus implying they will take a more detailed research not only from a mechanical or pharmacological point of view, yet also from the stance of living tissue response, i.e. biocompatibility. This makes finding the optimal option a harder process, which hampers introduction of innovation-based solution into practical healthcare [32-34, 39-41], whereas the ultimate goal of such solutions would be obtaining results that could ensure full reparative regeneration processes, thus bringing about mechanical integrity of the connection between the implant and the bone. At the moment, there is a stable opinion 
stating that bone development on the implant surface implies two types of bone formation processes - contact osseogenesis, which is on the implant surface, and distant osseogenesis, i.e. from the maternal bone. These mechanisms feature their own specifics, but they share common cellular processes including proliferation and osseogenic differentiation of their own mesenchymal stem cells; the formation of osteoblastic cells that shape the bone, which is to undergo rearrangement later on.

Some experts believe that the contact and mechanical connection of the titanium surface - bone interface is of key importance to the morphology of the implant surface. Developing a strong connection with the bone tissue takes a certain biological activity from the implant surface structure, apart from its wellstudied properties. The available scientific literature claim there are various options proposed to resolve the issues within the implant surface - living cell system. Thus study implied investigating the systems for implant surface preparing with hydroxyapatite, which is used widely in dentistry, yet remains questionable concerning its clinical implementation [32-37, 40].

to develop and offer an in vitro-proven explanation Aim of study: for a technology of safe preparing of implants surface, which is to be done through studying the biocompatibility with human tissues, involving cell technologies.

\section{MATERIALS AND METHODS}

To test the biological compatibility and tropism for various types of cells, we obtained titanium samples from the Research Company Plasma Povolzhya (Saratov, Russia): Sample 1 - with neither coating nor sandblasting; Sample 2 - with titanium + hydroxyapatite (HA) coating. Osteoblast cultures and human dermal fibroblasts were used as the test systems. A total of 18 million dermal fibroblasts and 18 million fibroblast-like osseogenic cells were grown to be used in further research. At passage 4, cells were identified using morphological, biochemical methods as well as flow cytometry. The biological compatibility was studied through a direct contact in Petri plates under similar conditions for cell cultivation. The test system used cells of passages 4-8. The Petri plates with cultures with no samples were used as test systems; those were passaged and observed along with the experimental ones. At plating, the dosage in all cases was 20 thousand cells $/ \mathrm{cm}^{2}\left(2 \cdot 10^{4}\right)$. The interaction between the object and the test system remained under observation for 7 days. A total of 60 cups were examined. After the observation period, histological preparations of cell cultures were made. In unfixed monolayer cells, neutral fat was detected with sudan IV and hematoxylin. The stained preparations were studied and photographed using an automatic analytical system including an Olympus CX 21 microscope, an Olympus C-4000 ZOOM digital camera, and a system unit based on an Intel Pentium 4 processor. A total of 200 preparations were studied.

\section{RESULTS AND DISCUSSION}

Biocompatibility examination for Sample 1, titanium. A day later, both in the control and experimental plates, using an inverted microscope, a uniform monolayer was identified, where cells had structural features typical of dermal fibroblasts, and a growth pattern in close proximity of the sample (Figure 1a). In the remote area, no change in the culture growth was observed either (Table 1).

After 4 days, the cells, both in the control and experimental cups, still failed to reach monolayer density (Figure 1b), while the cells still retained their morphological and functional features both close to the sample and in the remote area.

A complete monolayer developed both in the control and in the experiment on Day 7. When stained with hematoxylin and sudan IV, the experiment fibroblasts were observed to retain structural features typical of healthy cells. The cell cytoplasm was oxyphilic and appeared to be homogeneous. The nuclei were of correct shape with smooth membranes. Neutral fat in fibroblasts was not detected (Figure 2a). Biocompatibility examination for Sample 2, HA coated titanium. In this study, the material did not affect the fibroblasts adhesive capacity in the culture. Observing the native culture through its dynamics revealed that 2 hours after transfer most of the cells adhered to the culture plastic and spread on it. After one day, the fibroblasts were expanded, joined their processes to each other, and began to develop a monolayer both close the sample (Figure 2b) and in the remote area. Fibroblasts, in their morpho-functional features, did not differ from cells located near the sample (Table 2).

On Day 4, the monolayer density increased slightly, both near the sample and in the remote area (Figure 3a). Cells were located in different directions. On Day 7 , the situation was not much different from that of Day 4. On Day 7 of the experiment, when staining fibroblasts with hematoxylin + sudan IV, an increase was observed in the number of processes that got intertwined. The cytoplasm of the cells was oxyphilic, homogeneous. The cytoplasm of single cells contained vacuoles. The nuclei were correct oval shape. Neutral fat was not detected (Figure 3b).

Given the above, the study involving the dermal fibroblasts culture showed no visible response to the 
samples, which suggests that the samples in question are inert for this group of cells.

Observation of the native culture of osseogenic fibroblast-like cells (Series 2, Sample 1) revealed that 2 hours into the transfer, most of the cells stuck to the culture plastic, and after 1 day spread on it. The cells began to develop a fairly uniform monolayer both around the periphery of the cup and in close proximity to the sample (Figure 4a). Cells did not differ in structure and growth nature from the control cultures. 4 days into the experiment, complete overgrowth of the cup bottom was observed both near the sample and along the periphery, while in some areas the growth pattern of the monolayer changed - the cell layers were located in different directions (Figure 4b).

The cells in those layers retained the fibroblastlike shape and fit together closely (Table 3).

After 7 days, some areas featured certain thinning of the monolayer if compared to the previous study periods. This was more obvious in close proximity to the sample rather than in remote areas (Figure 5a). The monolayer histological preparations, when stained with hematoxylin and sudan IV through these stages, showed osseogenic cells near the sample, which were located randomly in various directions. The cells changed their shape from fusiform to rhomboid. The processes thickened with their outlines becoming clearly cut. The cytoplasm of the cells was oxyphilic and appeared to be homogeneous. The nuclei were of different size of correct oval shape, with smooth membranes; chromatin had the shape of fine grain, with diffuse location. There were double nucleus cells to be observed. No neutral fat was detected in the cytoplasm (Figure 5b).

When observing the osseogenic fibroblast-like cells culture (Series 2, Sample 2), we could identify that 2 hours into the transfer, a small number of cells stuck to the culture plastic spreading on it. On Day 1, osseogenic fibroblast-like cells began to develop an uneven monolayer, and got connected to one another with their processes (Figure 6a). On Day 4, the number of cells over the entire surface increased slightly; the cells were interconnected with their processes. The monolayer was uneven (Figure 6b).

On Day 7, the number of the cells increased slightly, both near the sample and in remote areas (Table 4).

Cells got interconnected with their shoots. The monolayer was uneven; the cells were located in different directions (Figure 7a). When stained with sudan IV and hematoxylin, the cells in close proximity to the sample were of different shape, with $2-5$ processes. The cytoplasm of the cells was oxyphilic and appeared homogeneous; certain cells had vacuoles of various shape and size. The nuclei were of different size, oval- and dumbbell-shaped. Fine-grain chromatin was diffusely located in the nuclei. The nucleoli were of various shape and size, 1 to 4 in the nucleus (Figure $7 \mathrm{~b}$ ).

The outcomes suggest that the experiment with the osseogenic fibroblast-like cells culture responded to the samples through impeded growth. Cells changed their shape from fusiform to rhomboid. There were double nucleus cells observed as well as nuclei of different size, oval and dumbbell-shaped. Some cells had vacuoles of various shape and size. This is indicative of a toxic effect that Sample 2 had on this group of cells.

\section{CONCLUSION}

1. The in vitro outcomes revealed that the response manifested by osseogenic fibroblast-like cells to titanium samples with hydroxyapatite coating and sandblasting, as well as to samples with no bioceramic layer was different.

2. Implant surface sandblasting is technologically reasonable, evidence to that being the maximum cell adhesion and a stimulating effect on cell proliferation.

3. No diagnostically significant functional change in the culture of osseogenic fibroblast-like cells was observed after studying with different surface structures of dental implants; while functional cytological differences fell within the normal range. Significant changes in the morphological features of the osseogenic fibroblast-like cells culture mean that hydroxyapatite applied via plasma spraying has a certain cytotoxic effect, which suggests that using bioceramic implants in surgical dentistry would not contribute to osseointegration at the molecular and cellular levels.

4. A comprehensive study of cell behavior and their interaction with tissue microenvironment will certainly lead to an understanding of regeneration activation; comprehensive growth regulation; cell death and differentiation, and in case advanced technologies become available, it would allow creating easy-to-use cell preparations or tissue-engineered structures to restore damaged tissues.

5. An objective study of tissue engineering regeneration capacity, which would allow restoring bone defects in the maxillofacial area, would take consistent preclinical and clinical trials controlled through laboratory and morphological research methods, which, in turn, might allow evaluating the severity and direction of regeneration process in its dynamics.

6. When preparing to introduce cell technologies, it is reasonable to establish the viability of the cells to be used, since a significant outcome can be achieved only with living cells, while using inactivated cells will have a weak stimulating effect. 

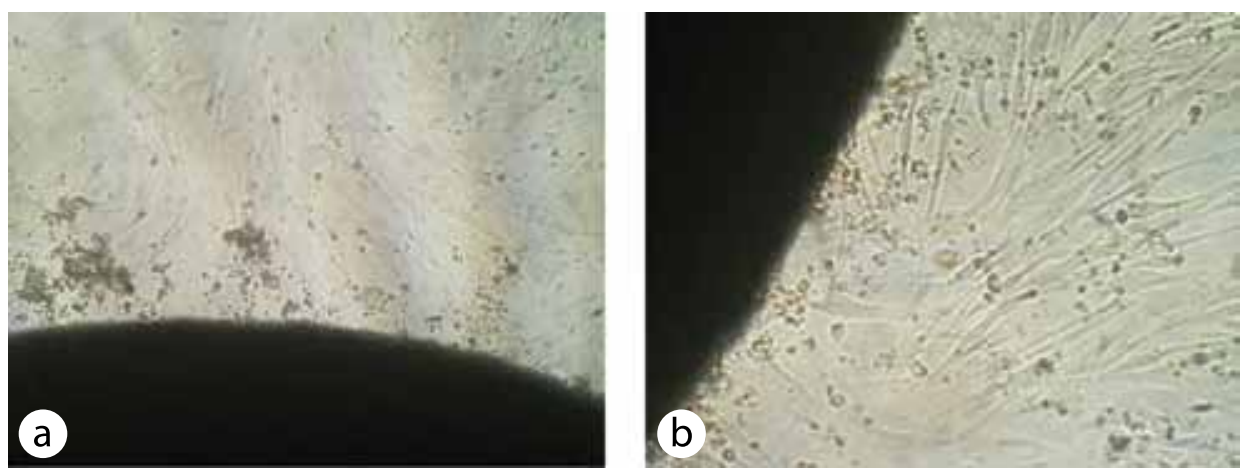

Fig. 1. a) Sample number 1. Native culture of fibroblasts. 1 day after sowing. fibroblast culture near the placed sample, b) - 4 days of the experiment. Inverted microscope. Magnification 150

Table 1. Morphological features of dermal fibroblasts culture

\begin{tabular}{l|l|l}
\hline Control group & Sample \# 1 & Sample \# 2 \\
\hline Spindle-shaped cells & + & + \\
\hline Number of shoots: 2-4 & + & + \\
\hline Homogeneous cytoplasm & + & + \\
\hline Clear cell boundaries & + & + \\
\hline The nuclei are oval in shape, are usually located somewhat eccentric, contain 1-2 nucleoli & + & + \\
\hline Good adhesion to plastic culture & + & + \\
\hline Absence of vacuoles & - & + \\
\hline Lack of neutral fat & - & - \\
\hline
\end{tabular}
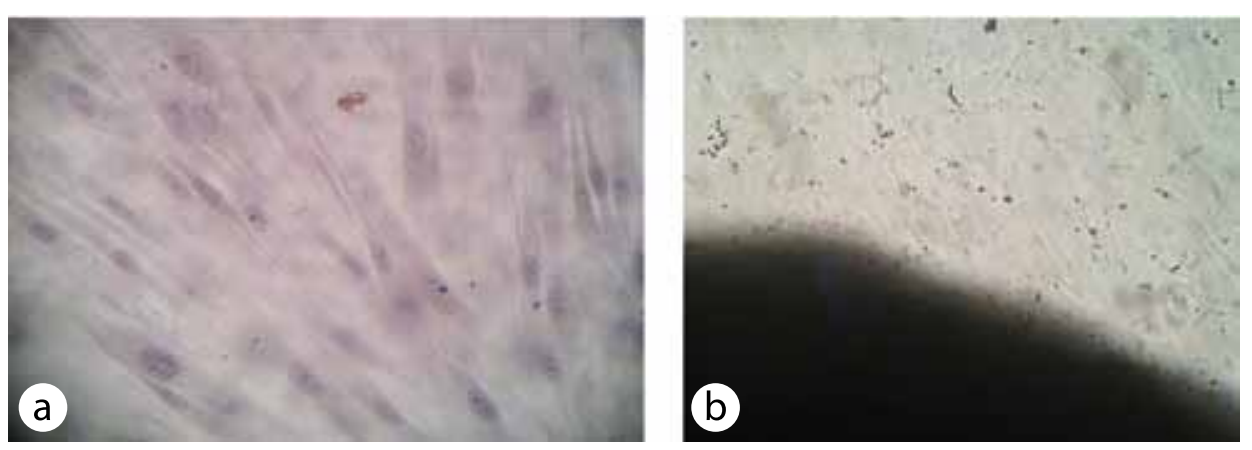

Fig. 2. a) Sample number 1. Culture of fibroblasts near the placed sample, monolayer. 7 days of the experiment. Coloring sudan IV and hematoxylin. H. 200; b) Sample number 2. Native fibroblast culture in the sample area. 1 day experiment. Inverted microscope. Magnification 100

Table 2. Functional features of dermal fibroblasts culture

\begin{tabular}{l|l|l}
\hline Control group & Sample \# 1 & Sample \# 2 \\
\hline After reseeding, most fibroblasts stick to the bottom of the culture dish and flatten it. & + & + \\
\hline Cells form an incomplete uniform monolayer & + & + \\
\hline Cells grow uniform monolayer & + & + \\
\hline The cells reach a saturation density and enter the stationary phase & + & + \\
\hline
\end{tabular}



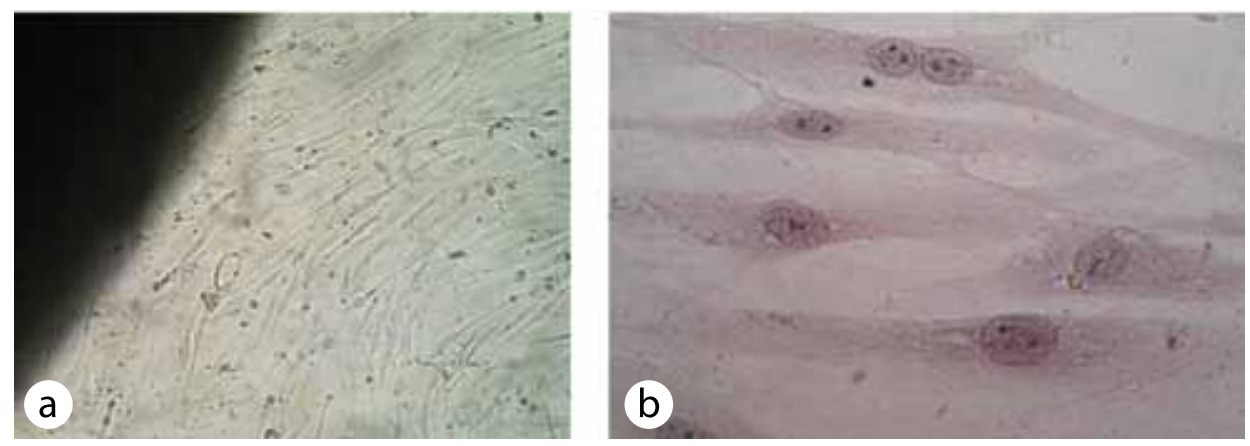

Fig. 3. a) Sample No. 2. Native fibroblast culture near the sample. 4 day experiment. Inverted microscope. UV 150; b) Sample No. 2.7 day experiment. Coloring sudan IV and hematoxylin. Magnification 200
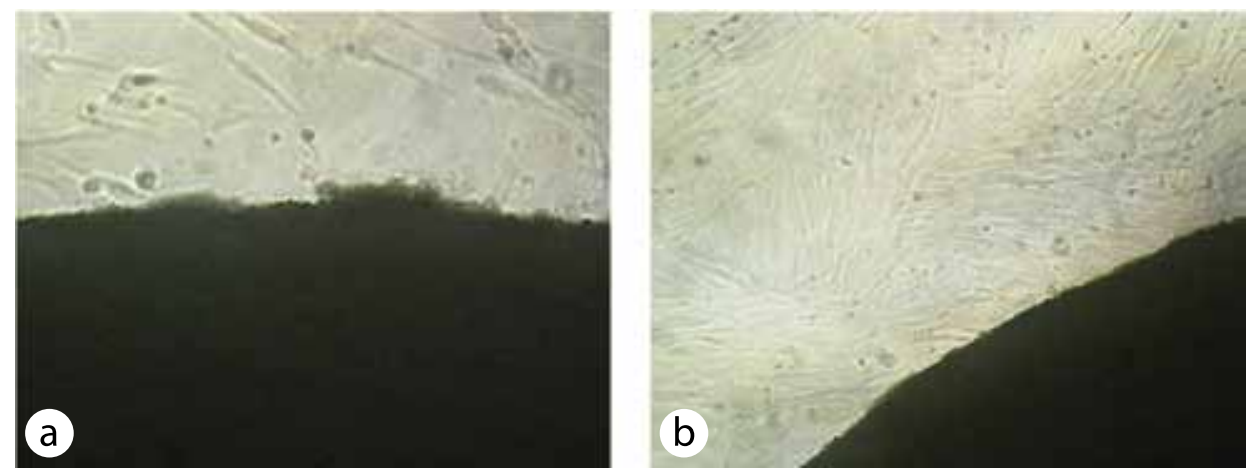

Fig. 4. a) Sample number 1. Native culture of osteogenic human fibroblast-like cells, 1 day experiment. Cells near the sample. Magnification 200. Inverted microscope; b) Sample No. 1. Native culture of osteogenic human fibroblast-like cells, 4 day experiment. Cells near the sample. Inverted microscope. Magnification 100.

Table 3. Morphological features of osseogenic fibroblast-like cells culture

\begin{tabular}{|c|c|c|}
\hline Control group & Sample \# 1 & Sample \# 2 \\
\hline Elongated cells with $2-5$ processes & + & $\begin{array}{l}\text { In the vicinity of the sample have a different } \\
\text { shape }\end{array}$ \\
\hline Homogeneous cytoplasm & + & + \\
\hline Clear cell boundaries & + & + \\
\hline $\begin{array}{l}\text { The nuclei are oval, usually located in the central } \\
\text { zone of the cell bodies, contain 1-2 nucleoli }\end{array}$ & $\begin{array}{l}\text { Change their shape from fusiform to diamond } \\
\text { shape. There are dual-core cells }\end{array}$ & $\begin{array}{l}\text { Kernels of different sizes oval and dumbbell } \\
\text { shaped }\end{array}$ \\
\hline Absence of vacuoles & - & $\begin{array}{l}\text { Some cells have vacuoles of various shapes } \\
\text { and sizes }\end{array}$ \\
\hline Neutral fat is missing & - & - \\
\hline
\end{tabular}
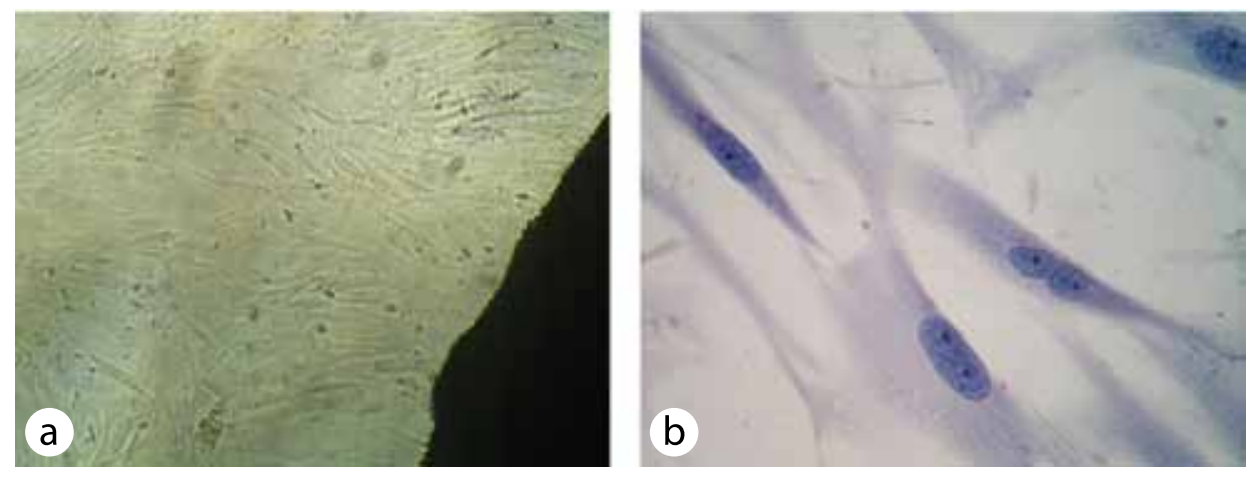

Fig. 5. a) Sample number 1. Native culture of osteogenic human fibroblast-like cells, 7 days of experiment. Cells near the sample. Inverted microscope. Increase 100; b) Culture of osteogenic human fibroblast-like cells near sample No. 1. Monolayer, 7 experiment. Stained with hematoxylin and sudan IV. Magnification 400. 

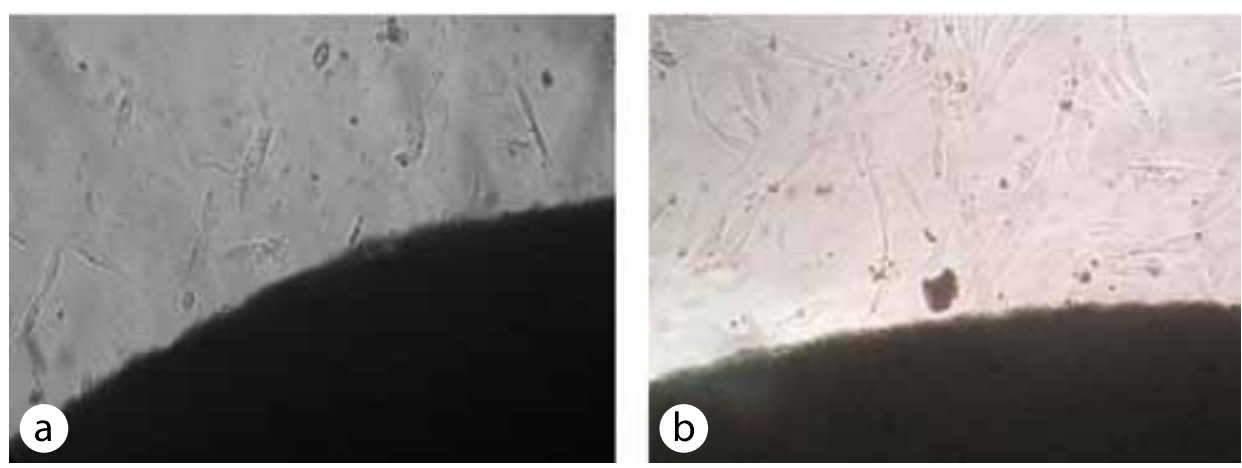

Fig. 6. a) Sample No. 2. Native culture of osteogenic human fibroblast-like cells, 4 passage. 1 day experiment. Cells near the sample. Inverted microscope. An increase of 200; b) Sample No. 2. Native culture of osteogenic human fibroblast-like cells, 4 days of experiment. Cells near the sample. Inverted microscope. Magnification 200.

Table 4. Functional features of osseogenic fibroblast-like cells culture

\begin{tabular}{|c|c|c|}
\hline Control group & Sample \# 1 & Sample \# 2 \\
\hline $\begin{array}{l}\text { Most fibroblasts stick to the bottom of the culture dish and spread } \\
\text { over it }\end{array}$ & + & + \\
\hline Cells form an incomplete uniform monolayer & + & + \\
\hline Cells grow uniform monolayer & + & + \\
\hline The cells form a complete monolayer, mostly in one direction & $\begin{array}{l}\text { Some monolayer discharge, more noticeably in the } \\
\text { immediate vicinity of the sample }\end{array}$ & + \\
\hline Well pronounced adhesion to culture plastic & + & + \\
\hline The cells reach a saturation density and enter the stationary phase & + & + \\
\hline
\end{tabular}
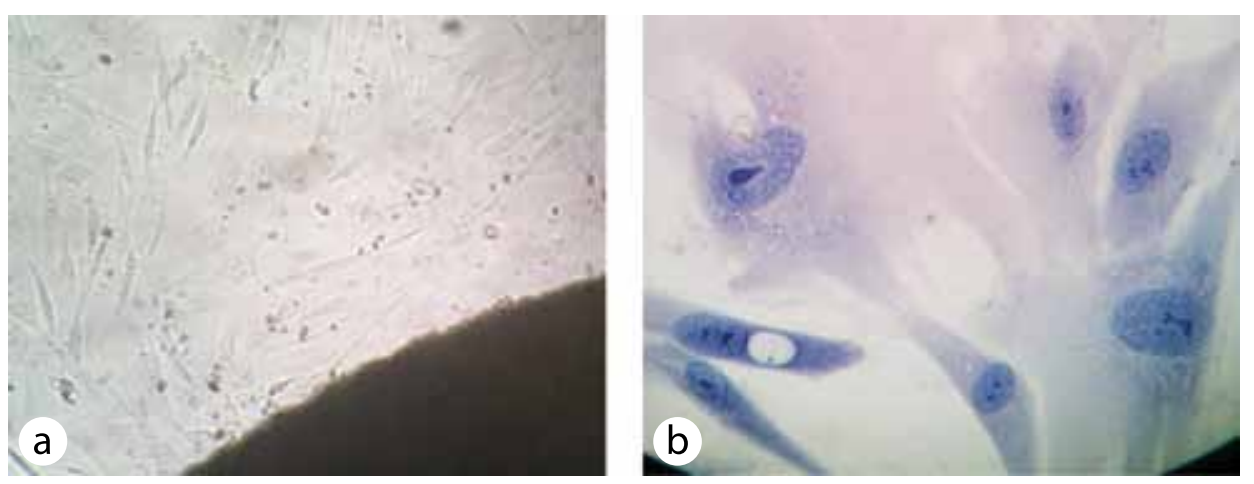

Fig. 7. a) Sample No. 2. Native culture of osteogenic human fibroblast-like cells, $7^{\text {th }}$ day of the experiment. Cells near the sample. Inverted microscope. An increase of 200; b) Culture of osteogenic human fibroblast cells. Cells near sample No. 2. Monolayer, 7 days of the experiment. Coloring sudan IV and hematoxylin. Magnification 400.

\section{REFERENCES}

1. Brunette D.M., Tengvall P., Textor M., Thomsen P. Titanium in Medicine: Material Science, Surface Science, Engineering, Biological Responses and Medical Applications (Engineering Materials) // Springer. - 2013. - 1019 p.

2. Ewers R., LAmbrecht J.T. Oral Implants: Bioactivating Concepts // Quintessence Pub Co. - 2013. $536 \mathrm{p}$.
3. LEPILIN A.V., DMITRIENKO S.V., DOMENYUK D.A., Puzdyryova M.N., Subbotin R.S. Dependence of stress strain of dental hard tissues and periodontal on horizontal deformation degree // Archiv EuroMedica. 2019. Vol. 9; 1: 173-174. https://doi. org/10.35630/2199-885X/2019/9/1/173

4. LePILIN A.V., Fomin I.V., DomenyUK D.A., DMitrienko S.V., Budaychiev G.M-A. Diagnostic value of cephalometric parameters at graphic 
reproduction of tooth dental arches in primary teeth occlusion // Archiv EuroMedica, 2018. Vol. 8. № 1. P. $37-38$.

5. SHKARIN V.V., DOMENYUK D.A., LEPILIN A.V., Fomin I.V., DMITRIENKo S.V. Odontometric indices fluctuation in people with physiological occlusion // Archiv EuroMedica, 2018. Vol. 8. № 1. P. 12-18.

6. Korobkeev A. A., Domenyuk D. A., SHKArin V. V., DMitrienko S. V., Mazharov V. N. Variability of odontometric indices in the aspect of sexual dimorphism. Medical News of North Caucasus. 2019;14(1.1):103-107. DOI - https://doi. org/10.14300/mnnc.2019.14062 (In Russ.)

7. KorobkeEv A.A., Domenyuk D.A., ShKarin V.V., DMitrienko S.V. Types of facial heart depth in physiological occlusion. Medical news of North Caucasus. 2018. - Vol. 13. - № 4. - P. 627-630. (In Russ., English abstract). DOI - https://doi.org/10.14300/ mnnc.2018.13122

8. Dmitrienko S.V., Davydov B.N., V.V. SHKarin, DoMENYUK D.A. Algorithm for determining the size of artificial teeth by the morphometric parameters of the face in people with full adentia. Dentistry. 2018; 97(6): 57-60. DOI - 10.17116/stomat20189706157

9. Domenyuk D.A., Vedeshina E.G., Dmitrienko S.V. Efficiency evaluation for integrated approach to choice of orthodontic and prosthetic treatments in patients with reduced gnathic region // Archiv EuroMedica. 2015. Vol. 5. № 2. P. 6-12.

10. Dmitrienko T.D., Domenyuk D.A., Porfyriadis M.P., ArutyunOVa A.G., KondratyUK A.A., Subbotin R.S. Connection between clinical and radiological torque of medial incisor at physiological occlusion // Archiv EuroMedica. 2019. Vol. 9. № 1. P. 29-37. https://doi.org/10.35630/2199$885 \mathrm{X} / 2019 / 9 / 1 / 29$

11. Domenyuk D.A., Davydov B.N., Dmitrienko S.V., Sumkina O.B., BudayChiev G. M-A. Changes of the morphological state of tissue of the paradontal complex in the dynamics of orthodontic transfer of teeth (experimental study). Periodontology, 2018; Vol. 23; 1-23(86): 69-78. DOI:10.25636/ PMP.1.2018.1.15

12. Domenyuk D.A., Dmitrienko S.V. Porfyriadis M.P. Major telerenthengogram indicators in people with various growth types of facial area // Archiv EuroMedica. 2018. Vol. 8. № 1. P. 19-24.

13. Fischev S.B., Puzdyryova M.N., DMitrienko S.V., Domenyuk D.A., Kondratyuk A.A. Morphological features of dentofacial area in peoples with dental arch issues combined with occlusion anomalies // Archiv EuroMedica. 2019. Vol. 9; 1: 162-163. https://doi.org/10.35630/2199-885X/2019/9/1/162

14. Gamborena I., Blatz M. Evolution: Contemporary Protocols for Anterior Single-tooth Implants // Quintessence Pub Co. - 2014. - 440 p.

15. Garazha S.N., Ivancheva Ye. N., Domenyuk D.A. A study of the surface of acryl-plastic-based fac- ing dental materials. Russian dental journal, 2010; 3: $4-8$.

16. Garazha S.N., Ivancheva Ye. N., Domenyuk D.A. Laser profilometry and scanning electron microscopy to study the surface structure of dental casting alloys of noble and precious metals. Russian dental journal, 2010; 3: 9-12.

17. Garazha S.N., Ivancheva Ye. N., Domenyuk D.A. Prognostication of the clinical efficacy of wholeceramic restorations taking into account microstructural peculiarities. Russian dental journal, 2010; 4: $10-12$.

18. Garazha S.N., Popov A.A., Borovok M.V. The use of electron scanning microscopy and laser profilometry to assess surface properties of dental composition materials. Russian dental journal, 2008; 3 : 14-18.

19. Broxmeyer H.F., Srour E., Orschell C. et Al. Cord blood stem cell and progenitor cells // Methods Enzymol.- 2006.- Vol. 419.- P. 439-473.

20. Basov A.A., IVChENKo L.G., DoMENYUK D.A., DMitrienko T.D., NuzhNaYa C.V. The role of oxidative stress in the pathogenesis of vascular complications in children with insulinable sugar diabetes // Archiv EuroMedica. 2019. Vol. 9; 1: 136-145. https:// doi.org/10.35630/2199-885X/2019/9/1/136

21. Domenyuk D.A., Porfyriadis M.P., BudayCHIEv G. M-A. Contemporary methodological approaches to diagnosing bone tissue disturbances in children with type 1 diabetes. Archiv EuroMedica, 2018; 8(2): 71-81.

22. Davydov B.N., Domenyuk D.A., BYKov I.M., IVCHENKo L.G., DMitrienko S.V. Modern possibilities of clinical-laboratory and $\mathrm{x}$-ray research in preclinical diagnostics and prediction of the risk of development of periodontal in children with sugar diabetes of the first type. Part I. Periodontology, 2018; Vol. 23; 3-23(88): 4-11. DOI:10.25636/PMP.1.2018.3.1

23. Domenyuk D.A., Davydov B.N., Dmitrienko S.V., Sumkina O.B., Budaychiev G. M-A. Changes of the morphological state of tissue of the paradontal complex in the dynamics of orthodontic transfer of teeth (experimental study). Periodontology, 2018; Vol. 23; 1-23(86): 69-78. DOI:10.25636/PMP.1.2018.1.15

24. Domenyuk D.A., Zelensky V.A., DMitrienko S.V., Anfinogenova O.I., Pushkin S.V. Peculiarities of phosphorine calcium exchange in the pathogenesis of dental caries in children with diabetes of the first type. Entomology and Applied Science Letters. 2018; 5(4): 49-64.

25. Domenyuk D.A., Shkarin V.V., Porfiriadis M.P., DMitrienko D.S., DMITRIENKo S.V. Algorithm for forecasting the shape and size of dent arches front part in case of their deformations and anomalies //Archiv EuroMedica, 2017. Vol. 7. № 2. P. 105-110.

26. Domenyuk D.A., Shkarin V.V., Porfiriadis M.P., DMitrienko D.S., DMitrienko S.V. Algorithm for forecasting the shape and size of dent arches 
front part in case of their deformations and anomalies //Archiv EuroMedica, 2017. Vol. 7. № 2. P. 105-110.

27. DMitrienko S.V., Domenyuk D.A., KochKonYAN A.S., KARSLIEVA A.G., DMITRIENKo D.S. Interrelation between sagittal and transversal sizes of maxillary dental arches // Archiv EuroMedica, 2014. Vol. 4. № 2. P. 10-13.

28. DMitrienko S.V., Domenyuk D.A., KochKonyan A.S., Karslieva A.G., DMitrienko D.S. Modern classification of dental arches // Archiv EuroMedica, 2014. Vol. 4. № 2. P. 14-16.

29. Domenyuk D.A., Shkarin V.V., Porfiriadis M.P., DMitrienko D.S., DMitrienko S.V. Classification of facial types in view of gnathology // Archiv EuroMedica, 2017. Vol. 7. № 1. P. 8-13.

30. Domenyuk D.A., Vedeshina E G., Dmitrienko S.V. Mistakes in Pont (Linder-Hart) method used for diagnosing abnormal dental arches in transversal plane // Archiv EuroMedica. 2016. Vol. 6. № 2. P. 23-26.

31. ShKarin V.V., Porfiriadis M.P., DOMENYUK D.A., Dmitrienko D.S., DMitriEnKo S.V. Setting reference points for key teeth location in case of abnormal dental arch shape // Archiv EuroMedica. 2017. Vol. 7. № 2. P. 111-117.

32. Amkhadova M.A., Nikitin A.A., Sipkin A.M. Risk factors and an algorithm for predicting postoperative complications with an increase in bone tissue in the region of the bottom of the maxillary sinus. // Dental journal. - 2009. - №2, June. - P. 182-184.

33. Rybakova U.S., IvaEv S.S., Ravodina D.V. The technology of creating biocompatible coatings on implants // Reshetnevskiye read 2016, p.341-342.

34. RYBakova, U.S., Ravodina, D.V. Selection of biocompatible composite coatings on implants. // Actual problems of aviation and astronautics. 2017. - Vol.2. P. 829-830.

35. Bubik S., Payer M., Arnetzl G., KaltenegGER H., LeithNer A., KLAMpfl A., LOHBERGER B. Attachment and growth of human osteoblasts on different biomaterial surfaces. // Int J Comput Dent. 2017; 20(3):229-243.

36. da Silva G.F., Cesário F., Garcia A.M.R., WeCKWERTH P.H., DUARTE M.A.H., DE Oliveira R.C., VIVAN R.R. Effect of association of nonsteroidal anti-inflammatory and antibiotic agents with calcium hydroxide pastes on their cytotoxicity and biocompatibility // Clin Oral Investig. 2019 May 28.

37. González-Blanco C., Rizo-Gorrita M., luna-Oliva I., Serrera-Figallo M.Á., TorresLagares D., Gutiérrez-PÉrez J.L. Human Osteoblast Cell Behaviour on Titanium Discs Treated with Argon Plasma// Materials (Basel). 2019 May $28 ; 12(11)$.

38. He W., Yin X., Xie L., LiU Z., Li J., Zou S., Chen J. Enhancing osseointegration of titanium implants through large-grit sandblasting combined with microarc oxidation surface modification // J. Mater Sci Mater Med. 2019 Jun 11;30(6):73.
39. Shahi S., Özcan M., Maleki Dizaj S., Sharifi S., Al-Haj Husain N., Eftekhari A., Ahmadian E. A review on potential toxicity of dental material and screening their biocompatibility // Toxicol Mech Methods. 2019 Jun; 29(5): 368-377.

40. Park S.J., Kim B.S., Gupta K.C., Lee D.Y., Kang I.K. Hydroxyapatite Nanorod-Modified Sand Blasted Titanium Disk for Endosseous Dental Implant Applications / Tissue Eng Regen Med. 2018 Aug 25;15(5): 601-614.

41. Wang H., Lin C., Zhang X., Lin K., Wang X., SHen S.G. Mussel-Inspired Polydopamine Coating: A General Strategy To Enhance Osteogenic Differentiation and Osseointegration for Diverse Implants // ACS Appl Mater Interfaces. 2019 Feb 20;11(7): 7615-7625. 